\title{
$1,000 \mathrm{~m}^{3} \mathrm{LNG}$ 実験船による波浪中航走実験 (第二報)
}

\author{
—タンク応力応答—
}

\begin{tabular}{|c|c|c|c|c|c|c|c|c|c|}
\hline 正員 & 堀 & & & 徹* & 正員 & 竹 & 沢 & 誠 & 二 $^{* *}$ \\
\hline 正員 & 片 & 坐 & 泰 & 治*** & 正員 & 原 & 田 & 耕 & 二*** \\
\hline & 田 & 畑 & 潤 & 一**** & & 清 & 水 & & 昇* \\
\hline & 田 & 中 & 雅 & 子* & & & & & \\
\hline
\end{tabular}

Test results by $1,000 \mathrm{~m}^{3}$ experimental LNG Ship at actual sea going (2nd report)

- Stress response of LNG tank -
by Tohru Hori, Member Seiji Takezawa, Member
Taiji Kataza, Member Kōji Harada, Member
Jun-ichi Tabata, Member Noboru Shimizu
Masako Tanaka

Summary

The recent outstanding development of computer, accompanied with such powerfull methods of analysis as FEM, has yielded the design concept "design by analysis" where the structures are not designed by "rules", but almost entirely by "analysis". In the application of the design based on the concept, the designers are required to analyse the each physical quantities as the stochastic valuables, and to prove the safety of the objective structures statistically.

Then it is the problems how to prove the rationality of the analysed values or, if the analysis have some difficulties how to correct those, because the stochastic valuables are too difficult, though not impossible, to be simulated artificially. And it can be said that the experiments under the natural conditions are the most reliable way to solve those problems.

In the sense above, Hitachi Zosen have built up the $1,000 \mathrm{~m}^{3}$ experimental LNG ship, where two types of tanks prismatic independent tank and spherical tank, were equiped. The several kinds of quantities such as ship motion, pressure and stress in the tanks and so on, were measured under the conditions where the ship ran on the actual sea. Those measured values were compiled to obtain the statistical distributions or the various kinds of the statistical quantities. And the method of analysis of the safety assessment which are being developed by Hitachi Zosen were checked by those experimental values and the problems which requires further research were pointed out.

In this report, as the 2 nd report, the results of the experiments as to the pressure and stress response to the ship motion, and the several kinds of the statistical distribution of stress are indicated and are investigated by the analysis.

\section{1 緒 言}

電子計算機の急激な発達とそれに台致した形で進めら れてきた解析法の進歩は, 構造物の安全性を全て解析に

$\begin{aligned} * & \text { 日立造船 (株) 技術研究所 } \\ * * & \text { 横浜国立大学工学部 } \\ * * * & \text { 日立造船 (株) 船舶設計本部 } \\ * * * * & \text { 日立造船 (株) 因島工場 }\end{aligned}$

よって確めようといらいわゆる “design by analysis” と呼ばれる設計概念をもたらしたものと考えられる。 この設計概念の特街は物理量を全て確率論的に取り扱 ら点にあると思われ，従来の決定論的な教え力とはかな り異質な要素を多く含んでいる。 この概念に従って解析を進めるためには確率変数とし ての各物理量の実体を毗む事が必要であるが，それらが 


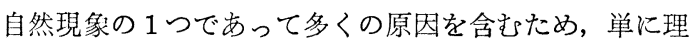
論のみでは実体をあきらかにする事が難しい場合も多い と考えられる。したがってまず実際を観察することによ って各物理量の発生の原因, 仕組などに目安をつけ解析 方法を開発していくことが必要ではないかと考えられ る。

そこで日立造船では総容量 $1,000 \mathrm{~m}^{3}$ の実験船を建造 し，実際の海面を航走する状態で各物理量の計測を行 ない,それら热験值に統計的な処理を加完実体の把握に 努めると共に現在開発中の解析手法の妥当性を見ると同 時に今後の問題点を明らかにすることに努めた。

今回は第二報として船体運動以後の問題, タンク内压 力, および応力の船体運動との応答関係や各種統計分布 について実験結果を示すと共に解析結果との比較検討を 行なっている。

\section{2 実験の背景}

\section{1 実験の目 的}

いわゆる B-Type の LNG 船タンクを建造するため には, タンクの安全性を解析によって証明する必要が少 る。つまり与えられた航路, 海面を基に波浪外力を推定 し, その波浪外力下での応力の評価, そして得られた応 力から疲労強度, Fracture Mechanics 強度などの強度 解析を行ないその安全性を確める必要がある。

しかるに，波浪外力またはそれに惹起される応力など は自然現象の一環として確率論的に取り扱ら必要があり その実体を研究窒内の実験などで把握するのは，はなは だ難しい事枢であると考学られる。

そこで当社では， $1,000 \mathrm{~m}^{3}$ の実験船を建造し，実際 の海面を航走させ船体運動，タンク内压力，応力などを 収録した。

これら収録された奏験データを解析し，各物理量間の 応答関係や統良的な先体を明らかにし, 現在当社が考兄 ている応力推起法が実際をどの程度反映しているものか を確認すると共に今後のより合理的な応力推定法の確立 に役立てることを目的としている。

\section{2 応力推定法}

当社が現在考えている㐫力推定の解析フローを Fig.1 に示す。この解析フローにはいくつかの前提条件が含ま れているが，そのらら主なものは次の 2 点である。

（i）タンクの載荷状態は満載状態のみを対象とす る。

（ii）応力推定に当って船とタンクの間の相互作用の 影響を無視する。

このうち（ii）については実用的な解析方法としては 致命的な欠陥と䍐われるが，その主旨はタンクに対する primary な外力であるタンク内生力による応力をまず
正確に評価し, 実験結果から逆に相互作用の影響を求め その実体を明らかにしよらとするものであって，正確に 評価しようとすればぼら大な計算を必要とする相互干渉 の影響をできるだけ簡単な計算で評価する方法を模索す る基礎データを得ようとする目的を背後に持ってい る。

解析フローのらち与えられた海面状態より船体運動を 得る過程については既に第一報1)で報告しており，解析 の結果は実験結果をよく説明して和り問題はないものと 考えられる。

本報告の対象は船体運動以後の過程であって, その解 析方法を以下に概説する。

（a）タンク重心位置における加速度成分

船体運動は計算の都合上タンクの重心位置に抢ける加 速度成分に置換される。つまり, 満載状態においてはタ ンク内の圧力を加速度成分によって一意的に決定できる ためである。したがって本報告の対象は確率変数として タンク重心位置に打ける加速度 3 成分が与兄られた場合 にタンク内圧力や応力がどのような確率変数として与え られるかといらことに要約できる。

（b） 加速度とタンク内圧力

タンクが満載の場合, タンク内圧力は重心位置での加 速度 3 成分の関数として求めることができる。詳細につ いては参考文献 2）に報告したが，ここではその結果に ついてのみ述べる。

Fig. 2 に示すよらに座標をとるものとする。つまりタ ンク重心位置を座標原点とし, 船の長さ方向, 幅方向, 上下方向に各々 $x_{1}, x_{2}, x_{3}$ 軸をとるものとする。このと き方形タンク，球型タンクの圧力は次のように表すこと ができる（なお式では压力を $\mathrm{kg} / \mathrm{cm}^{2}$, 長さを $\mathrm{m}$, 加速 度をgで表するのとする)。

方形タンクの場合

$$
\begin{aligned}
p^{p}\left(x_{1}, x_{2}, x_{3}\right)= & \sum_{i=1}^{3} p_{i}^{p}\left(x_{1}, x_{2}, x_{3}\right) \cdot A_{i}+p_{0} \\
& +0.1 \rho \sum_{i=1}^{3} \frac{l_{i}}{2}\left|A_{i}\right|
\end{aligned}
$$

ここに, $A_{1}, A_{2}, A_{3}$ はタンク重心位置に打ける加速 度成分を表す。 $\rho$ はタンク内液体の比重を表す。

$p^{p}\left(x_{1}, x_{2}, x_{3}\right)$ は加速度 $\left(A_{1}, A_{2}, A_{3}\right)$ 下に和ける点 $\left(x_{1}, x_{2}, x_{3}\right)$ に打ける圧力を表す。

$p_{i}^{p}\left(x_{1}, x_{2}, x_{3}\right)$ は, 単位の各加速度成分が単独に働き, タンク重心位置の圧力を 0 とした場合の点 $\left(x_{1}, x_{2}, x_{3}\right)$ に拈ける压力値を表す (Fig.3 参照)。

$l_{1}, l_{2}, l_{3}$ はタンクの大きさを表し, 各々長さ, 幅, 深 さに対応する。

球形タンクの場合

$$
p^{s}(\theta, \varphi)=\sum_{i=1}^{3} p_{i} s(\theta, \varphi) \cdot A_{i}+p_{0}+0.1 \rho \cdot R \sqrt{\sum_{i=1}^{3} A_{i}{ }^{2}}
$$




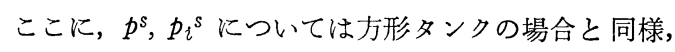
$R$ は球型タンクの曲率半径を表す。

なお式中の $\theta, \varphi$ については Fig. 2 を参照。

式（1）（2）において圧力は加速度成分についての非 線型の関数となっている。これは head point つまりタ ンク内の蒸気圧に圧力が等しくなる位置が一定せず加速 度の方向によって移動するためである。

(c) 加速度と応力

もし船とタンクの間の相互作用の影響を無視するとす れば,タンク内の応力はタンク内圧力が与えられれば一 意的に決定できる。しかるに圧力は加速度の関数として 表すことが可能であるから応力についても加速度の関数 として表すことができる。

つまり式（1）で表される圧力から圧力分布を求め夕 ンクに加わる外力と考えると, 例えば方形タンクの場合

$$
\boldsymbol{p}^{p}=\sum_{i=1}^{3} \boldsymbol{p}_{i}^{p} A_{i}+\left(p_{0}+0.1 \rho \sum_{i=1}^{3} \frac{l_{i}}{2}\left|A_{i}\right|\right) \boldsymbol{p}_{0}
$$

ここに, $\boldsymbol{p}_{1}{ }^{p} \sim \boldsymbol{p}_{3}{ }^{p}$ は各単位加速度成分が単独に働いた 場合の压力分布を表す (Fig. 3 参照)。

$p_{0}$ は単位蒸気圧に対応する圧力分布 (Fig. 3 参照)。

そこで Fig.3 の 4つの外力 (压力) 分布について応力 解析を行ない, タンク内の任意の 1 点 $\mathrm{Q}$ における応力值 を $\sigma_{0}{ }^{Q}, \sigma_{1}{ }^{Q} \sim \sigma_{3}{ }^{Q}$ とすれば，加速度 $\left(A_{1}, A_{2}, A_{3}\right)$ 下にお 壮る点 $\mathrm{Q}$ の応力 $\sigma^{Q}$ は, 重ね合わせの原理より次のよう に与えることができる。

$$
\sigma^{Q}=\sum_{i=1}^{3} \sigma_{i}^{Q} A_{i}+\left(p_{0}+0.1 \rho \sum_{i=1}^{3} \frac{l_{i}}{2}\left|A_{i}\right|\right) \sigma_{0}^{Q}
$$

式（1）および（4）を比較すると圧力および応力は 全く同じ形式の関数として表されていることが判る。球 型タンクについても同様に求めることができるがここで は省く。

（d）各種応力值の統計分布

（c）において応力が加速度成分の関数として表わさ れることを示したが，ここで応力の構成変数である加速 度を確率変数とした場合, 応力はどのような確率変数と なるかを求める必要がある。

このためにはまずどのような形の応力値を知る必要が あるかが問題となり，そのためには得られた応力值をど のような強度解析に適用して安全性を評価するかが問題 となる。LNG 船タンクの場合, 疲労解析, Fracture Mechanics 解析 (Leak Before Failure) 抢よび許容応 力の 3 本立てで評価することになっている。これら $3 つ$ の評価方法のうち, 前者 2 つ場合, ぞのような応力值 の確率分布が必要かということについては必ずしもはっ きりしていないのが現状ではないかと考えられるが，現 状では応力振幅 (stress range) の分布, 極值の分布お よび応力時系列そのものの分布を考えておけば十分では
ないかと考えられる。

これらの分布のらち, 時系列については正規分布, 極 値については Cartwright \& Longuet-Higgins の分布 になることが知れており，振幅についてははっきりした 理論分布は見当らないが数值実験の結果, 越智の Truncated 分布で近似しうることを報告している（参考文献 2) 参照)。

この 3 つの理論分布を決定するパラメータは時系列の 分散拉よび時系列に関するパワースペクトラムの相対的 な広がりの程度を表すバンド幅の 2 つであり，この $2 つ$ を求めることができればとりあえず問題は解決する。

これらの值を求めるに当って船体運動解析から与兄ら れる情報は各加速度成分のパワースペクトラム, および 分散であって必要ならば各加速度間の相関係数も得るこ とができるが，相関関係を考慮すると問題はかなり複雑 化するものと考えられ，とりあえず相関関係を無視し， 各加速度成分は統計的に独立と考えることにすれば，問 題は関数の確率分布を求める問題に帰することができ る。

以下に分散およびバンド幅の求め方および問題点を述 ベる。

（i）分散

関数が線型であれば簡単にいわゆる square root 法 によって求めることができるが, 問題は式（4）に示さ れるよらに関数が非線型の場合であって, この場合の近 似法については既に報告しているが（参考文献 2)）, こ こではその結果のみについて述べると，(4) 式のよう な関数の分散を求める問題は以下に示すような簡略化し た関数の分散を求めることに帰着させることができる。

$$
Y=k_{0}+k_{1} x_{1}+k_{2} x_{2}+k_{3} x_{3}+k_{4}\left|x_{1}\right|+k_{5}\left|x_{2}\right| \quad \text { （5） }
$$

ここに, $k_{0} \sim k_{5}$ は定数, $x_{1} \sim x_{3}$ は関数 $Y$ の従属变数 であり，その平均值が $0,0,1$, 分散が $\sigma_{1}{ }^{2}, \sigma_{2}{ }^{2}, \sigma_{3}{ }^{2}$ で ある確率変数と考える。

このとき関数 $Y$ の平均值は

$$
E(Y)=k_{0}+k_{3}+k_{4} \sqrt{\frac{2}{\pi}} \sigma_{1}+k_{5} \sqrt{\frac{2}{\pi}} \sigma_{2}
$$

分散は

$$
\begin{aligned}
D(Y)= & k_{1}{ }^{2} \sigma_{1}{ }^{2}+k_{2}{ }^{2} \sigma_{2}{ }^{2}+k_{3}{ }^{2} \sigma_{3}{ }^{2} \\
& +k_{4}{ }^{2} \frac{\pi-2}{\pi} \sigma_{1}{ }^{2}+k_{5}{ }^{2} \frac{\pi-2}{\pi} \sigma_{2}{ }^{2}
\end{aligned}
$$

と求めることができる。

(ii） バンド幅

関数のバンド幅の求め方については殆ど知られていな い。ここでは関数が線型の場合についてのみ考えること にする。簡単のため関数関係を次のように斐示する。

$$
Y=k_{1} x_{1}+k_{2} x_{2}+k_{3} x_{3}
$$

もし従属变数 $x_{1} \sim x_{3}$ のスペクトラム分布 $E_{1}(\omega), E_{2}$ 
$(\omega), E_{3}(\omega)$ が与光られ，末た $x_{1} \sim x_{3}$ が統計的に独立 ならば $Y$ なスペクトラムは以下のように求めることがで きる。

$$
E_{Y}(\omega)=k_{1}^{2} E_{1}(\omega)+k_{2}^{2} E_{2}(\omega)+k_{3}^{2} E_{3}(\omega)
$$

$Y$ のスペクトラムが走まるので，バンド幅は各々の方 法で計算することができる3゙。

(iii) 問 題 点

与えられた海面比いて，波と船とのなす角度 (Heading Angle) を一定に保ち航行するとすれば, タンク重 心位置の各加速度润に当然いくらかの相関関係が存在す るものと教えられる。しかし，もしいくつかの Heading Angle に持壮る加速度を瑟積すれば相関関係はかなり娍 少し, 結果として相関関係を然視してもよい予測值を期

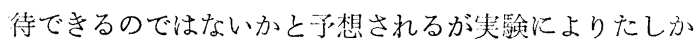
める必要がある。一ガバンド蹗については現状では確か な方法がないが，バンド幅係数にが $0.3 \sim 0.4$ 以下で少 孔ば Cartwright \& Longuet-Higgins の分布は実質的 飞 Rayleigh 分布で衣すことができ，バンド幅の影篦を 無視できるといわれている5。したがって応力が実際に はどの程度のバンド幅を持っているのか资笑騟により磪 める必要がある。

\section{3 実 験 の 概 要}

\section{1 計測項目および位置}

Fig. 4 に笑験に用いられた $1,000 \mathrm{~m}^{3}$ 穾験船の Profile を示す。困にみられるごとく本船は方形タンク打よび球 型タンクを搭載しており两タンクに対して実験が行なわ れた。

本実験では多くの目的に従って訃測が行なわれてお り，計测された垻目も多岐にわたっているが，ここでは 本報告に関連市る項目についてのみ説明することにす る。

(a) 加 速 度

加速度は本来波に対する船体運動の伈答学見るために 計測するのであるが，タンクに対する外力の原因として 船体運動を考えるときには，2 章で述べたごとく，タン ク重心位置に打ける加速度 3 成分の形で求めた方が都合 がよい。そこで方形, 球型雨タンクについてその重心位 置で加速度の 3 成分が計測された。

(b) 压 打

船信運動によってタンク内に压扔が発生し, 発生した 王力によって応力が荵起される。したがって応力を正し く評価するためには，历力が正しく評価される必要があ りかなり詳しく計泪を行なった。

方形タンクについては Fig. 5 に示すように 12 力所で, 球型タンクについてはFig. 6 亿示すように15力所で咸う が計測されている。な拈ゲージとしては共和電業製 $\mathrm{BE}$
$-2 \mathrm{~KB}$ ，誼径 $94 \mathrm{~mm}$ の土E計を使用した。

(c) 応 力

応力の計測は計測技術上かなり難しい問題であるの で, 計测簀所の決定に当っては可能なかぎり信頼性の高 い計測值が得られることを念頭においた。

Fig.7 にはホリゾンタルに括けるゲージ貼布位置, Fig. 8 にはトランスリングに拈けるゲージ貼布位置を示 す。図には他の目的で貼布されたゲージも合わせて表示 されているが，本報告の対象となるゲージはホリゾンタ ルでは H 1, H 5, H7, H 8, H 95 点, トランスリン グでは T 1, T 3, T 6, T 9, T 10 の 5 点である。

な稀型タンクについても応力部測を行なっているが 末だ解析の段階に至っていないのでここでは説明を省略 する。

事た胡測值の安定をはかるため, $1 \mathrm{k} \Omega$ の抵抗と $33 \mu \mathrm{F}$ のコンデンサで構成されるフィルターを, 全ての計測点 （加速度, 压力, 応力とも) にほどこしている。

\section{2 計 測 方 法}

\section{(a) 実駼海域および日時}

突筌は Fig. 9 で示される海域で眧和 49 年 6 月 12 日か 57月12日末での間で比較的海が荒れている日を選ん で計測が行なわれた。幸い台風に遭遇する機会に恵まれ ほ涪所期のデータ収録汇成功したもの之考えられる。

（b）タンクの載荷状態

タンクは満載, $75 \%$ フル，50\%フルの状態で計測さ れたが，本報曻ではこのらら満載状態に対するものを対 象としている。

(c) 実験方法

过験の目的は考兄られた海面に拈ける各物理鼠の統計 的な諸目を求めることに少るが，これらは波と船がなす 侍 (Heading Angle) の関数と考えられる。そこで実験 では1つの海面に対していくつかの Heading Angleを とり, 各々の Heading Angle についておよそ $20 \mathrm{~min}$ の萑続計測を行なっている。このようにすることによっ て各 Heading Angle に対するデータを求めると同時 に，全ての Heading Angle に対する統計量を累積する ことによって, Heading Angle の影響を取り除いた状 態, いわゆる All Heading の状態に対応する統計量を 求めようとしたものである。以上の事俪艺 Table 1 に まとめて示す。

データ収録機ししてはディジタルデータレコーダー (DATAC 1500) 1 台およびアナトグデータレコーダー 5 台（TEAC R-251）が使用された。本報告で示すデー 壮主として DATAC 1500 によって収録されたもので 监って, 合計 63 個の物理留が約 0.4 秒のサンプリング タイムでディジタル化され同時に収録されている。 


\section{4 実験結果および考察}

2 章に述べた背景のもとに実騟の結果および解析值と の比較を以下に述べる。

\section{1 Time History}

2 章で述べた如く，応力の推定に当ってまず前提とな るのは, 応力が加速度の関数として表されることにあっ た。そこで応力が加速度の関数として表せるものかどう か，またその関数式の妥当性はどうかという問題を謂べ るためには Time History の比較が有効である。

つまり加速度の関数として（4）式が与えられ, 時々 刻々の加速度成分が与えら礼た之すれば，それらの加速 度值を（4）式に代入すれば1つの応力に対する Time Historyをらることができる。これを歪ゲージから值接 計測された実験值としての Time History と比較すれ ば（4）式の妥当性を見ることができる。

ただ応力についてはその值を決定する要因が加速度も しくはそれによって惹起されるタンク内玨力だけではな く, 船とタンクの間の相互作用の影響があって上記の比 較のみでは（4）式の妥当性を見ることができない。幸 いタンク内压力も加速度の関数として表らわされており その関数の形は灾力に関するものと同じである。したが ってまず压うの Time History に関する上記の比較を 行ならことによって咸数式の妥当性を確認できるものと 考えられる。

また応力について上記の比較を行えば，両者に相違が あれば，その差は船とタンクの問の相互作用の影響を示 すと考光られる。

(a) 加速度の Time History

Fig.10 に加速度の Time History の例を示す。加速 度は方形タンク重心位置で計測されており, 各々前後, 左右, 上下の方向の加速度を示している。

これら加速度の Time History は以下の圧力, 応力 の Time History の比較の基になるものであって，こ れらの Time History から時々刻々の加速度成分值が 読みとられ訃算上の压力, 応力の Time History が求 められている。

(b) 压力の Time History

タンク内応力值を決定する primary な外力である夕 ンク内圧力を正しく推定できるかどうかは非常に重要な 問題と考完られる。

Time History の比较に祭し, 推定式（1）は実験状 態に合わせ若干修正する必要がある。つまり（1）式に おいては压力の Head Point が加速度の方向に従って移 動することを考虑している。しかるに実験状態ではタン ク内の各種ゲージの導線をとり出すためにタンクのトッ ププレート中央にもらけられたハッチのふたをとりはず
している。したがってハッチ部に存在する自由表面で は常に大気化に等しくなり，ここが加速度方向に拘らず Head Point になっている。この点を考虑すると（1）式 は実験状態に対し次式のように修正される。

$$
\begin{aligned}
p^{p}\left(x_{1}, x_{2}, x_{3}\right)= & \sum_{i=1}^{3} p_{i} p\left(x_{1}, x_{2}, x_{3}\right) \cdot A_{i} \\
& +0.1 \rho \frac{l_{3}}{2} \cdot A_{3}
\end{aligned}
$$

同様の理由で応力の推定式 (4) も次式のように修正 される。

$$
\sigma^{Q}=\sum_{i=1}^{3} \sigma_{i}^{Q} A_{i}+0.1 \rho \frac{l_{3}}{2} \cdot A_{3} \sigma_{0}{ }^{Q}
$$

(10)，(11）式から判るように実験状態においては，历 力, 応力は加速度に関して線型の関数となり, 実際の夕 ンク状態で現れる非線型の影響については本実験では見 ることができなかった。

Fig.11 に加速度の Time History から読みとられた 各加速度成分值を推定式 (10)に代入して得られたTime History と，圧力計から直接得られた Time Historyの 比較例を示す。

眓にみるごとく雨者は非常によい一致をみせている。 比較は他の実験ケース，生力計測位置についても行なわ れているが，いずれも非常によい一致を見ることが判っ た。

したがって，タンク重心位置での加速度成分が判れば タンク内压力は十分の精度で予測できることが確認でき るものと思われる。また同時に本実験での各計测值が十 分信頼に足るものであることをも示すものと考孚られ る。

(c) 応力の Time History

応力を推定するためには (11) 式に和ける $\sigma_{0}{ }^{Q} \sim \sigma_{3}{ }^{Q}$ を 決定する必要があり， $\sigma_{0}{ }^{Q} \sim \sigma_{3}{ }^{Q}$ は Fig. 3 に示す外力に ついて応力解析を行ない, 点 $\mathrm{Q}$ に拈ける応力を求めるこ とによって決定できる。

そこで有限要素法による応力解析を行なった。Fig. 12 は計算に用いられたタンクの型素分割图であって約 17,000 個の節点（約 37,000 自由度）が含まれている。 境界条件としては船からの相互作用の影樂を除くため, タンクのキー, サポートの船との接触位置において变位 を拘束している。計算には当社開発のプログラム MAP が使用された5)。

計算の精度を確めるために，タンクが陸上で建造完成 した時にいくつかの静的実験を行ない，上記の要素分 割, プログラムで計算し比較を行なった。その結果は非

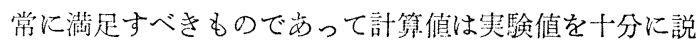
明できるものであった。

計算の結果, Fig.3 の各荷重パターンに対応する実験 各点の応力係数 $\sigma_{0} \sim \sigma_{3}$ を Table 2 に示す。 
Table 2 の各偵を（10）式に代入し, 更に各加速度成 分值を代入すればタンク内の圧力に起因する Time History になるであろらことは前述の過程から明らかな ものと考えられる。

Fig.13，Fig.14 はこのようにして得られた計算上の Time History と奏験計測から得られた Time History を比較したものである。図は両者が比較的よくあらもの と相異が最もはげしいものを選んで示したものである が，雨者の差が船とタンクとの相互作用の影響を表すと すれば，最も影罃の小さい例と大きい例を示したことに なる。

相互作用の影響をさらに詳しくみるために㒳時系列の 標準偏差をとり，各 Heading Angle ごとに示したのが Table 3 である。Table 3 にみるごとく実験点 T 9 で

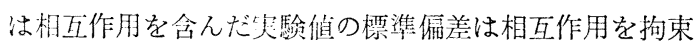
した訃算值の椤準作差に比べ 80〜100\%の大ささである のに区し，H5 では 30６0\% と大きく減少している。

この現像を裏付ける 1 つの例として次のようなデータ がある。

同じく $1,000 \mathrm{~m}^{3}$ 实験船において岸壁係留中に方形タ ンクに注水テストを行ない応力計測して計算值との比較 を行なっている。解析は船特よびタンクを梁要素で分割 することによって行なわれた（自由度約 4,650)。その 結果, タンクが空の状態から渾琙状態に至る差として H 5 の応力は実験值执よび訣筧值とも $3.5 \mathrm{~kg} / \mathrm{mm}^{2}$ の值 を得た。一方同じ焦荷状態に刘して相五作用を拘束した

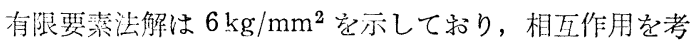
虑することによって応力が $60 \%$ 程度減少することを示 している。同様の比㕮をT 9 で行ならと雨者には汪と

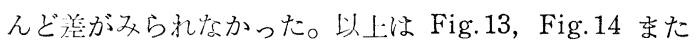
は Table 3 に現れる差を㖕付けるものの1つと考えら れる。

次に Fig.14 Kみるごとく，相互作用の大きいるので も,その変化の様子はほとんど同じで,ちょうど振輻を定 数倍したような形になっている。これは相互作用の影響 をサホート，キーに郝子る文持条件で四变变らる可能 性を示しているもの之教えられる。つまり相互作用によ る外力が加速度による外力（タンク内圧力による外力） とは独立な外力であれば Fig.13 の两 Time History は変化を様子の含めて相遠するものと考光られるからで ある。この点については更に柃詩を行ないたいと考えて いる。

\section{2 統 計 值}

2 章で述べた如く各種灾力倠の統計分布を溃定するた わには分散，およびバンド幅が必要である。ここでは実 験值と 2 章で述べた訃算式による值を比較检討する。

（a）分散
分散の予測に当っての問題点は応力計算式に乱ける非 線型の取扱亡徉属变数で市る加速度成分間に存在する相 関関係の影響の程度をしらべることであった。しかるに 前者については，実験状態で関数が線型となり，比較の 対象とならないため, 後者についてのみ述べる。

加速度成分の Time History から (11) 式を介して得 られる応力の Time History は加速度成分間の相関の 影響を含んでいる。そこでこの Time History から得 られた分散と（7）による計算値を比較すれば相関の影 㦒をみることができる。

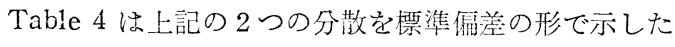
ものである。この表に示したものは比較的相関の影響が 少ない例であり, 場合によっては $30 \%$ 程度の相違を示す ものもあったが，いずれにしてもいくつかの Heading Angle による值を累積すると影響は小さくなり, 最も相 違の大きいものでも 10\% 以下の相違であることが判っ た。

(b) バンド幅

バンド幅の場合, その計算方法がいろいろ市り今回の 実験の場合, 詮算方法の相淟によってかなり值がばらつ いた。Table 5 は数値実験の Time History に拈いて 負の極大値の制会からバンド幅を求めたものと，(9)式 に示すごとく加速度成分の各スペクトラムを線型重社合 わせることによって応力のスペクトラムを求め, その各 モーメント値から計算されたバンド幅を比較したもので ある。前者は相関の影響を含んでおり, 後者は含んでい ないため, 雨者の差は相阅の影響を表すと解せられるが， Sample 数が少ないこと, および計算方法の相異などが あってダイレクトに相関の影響とはいえないのではない かと思われる。

注目されるのはいずれにしてもかなり大きなバンド輻 を示すことでするが，（9）式から判るよらにいくつか のスペクトラムが重なり合うため必然的に広いバンド幅 になるものと考えられる。

\section{3 統 計 分 布}

応计栖価以後の諸強度解析を念頭に応力時系列, 応力 極俇，伈力振幅に関する確率分布を実験結果から求め, 各々の分布に対応すると考劣られる理論分布との比較を 行なった。

1つの海面で 1 つの Heading Angle をとって船を航 走させ礼ば定常状態にあるものと考えられ，2章に述べ たごとく応力時系列に执ける各瞬時の応力傎の分布, 極 值の分布，掁幅の分布はそれぞれ正規分布，Cartwright \& Longuet-Higgins の分布就よび Truncated 分析にな ることが予想される。

Fig.15, Fig.16, Fig.17 はそれぞれ応力時系列, 極大 值，振幅に関する実験檤および各々に刘応する理論分布 
を比較したるのである。理論分布に用いられる分散は応 力の Time History から直接 2 乗平均をとって計算さ れ，バンド幅は同じくTime Historyに拈ける負の極 大值の割合から計算したものである。

図にみるごとく応力時系列については両者は非常によ く合致して括り, 極值, 振幅についてもサンプル数の少 なさによるものと考えられるバラッキが見られるものの 理論分布はよく実験値を説明しているものと考学られ る。今後 $\chi^{2}$-検定などによってさらに詳しく検定を行な いたいと考劣ている。

\section{5 結言}

$1,000 \mathrm{~m}^{3}$ 実験船による実海面で行われた実験の計測 值をもとに現在考えられている応力推定法の妥当性また は今後の問題点なぞについて検討を行なった結果につい て報告した。

最後に実験実施に当って有益なご指示，ご指導をして いただいた阪大寺沢名誉教授をはじめ，当社 HL 委に出 席下さった諸先生方に心から礼を申し上げる。
なお本実験は全社を挙げて行われたもので関係各位に お礼を申し上げるが，特に応力解析関係を受村持ってい たたいた船舶基本設計の各位，また実験の実施に当って 限りない協力をして下さった因島工場の各位の努力に負 ら所が大きかったことを申しそえる。

\section{参 考文 献}

1）浅野他：1,000 $\mathrm{m}^{3}$ 実験船による波浪中航走実験 (第一報), 日本造船学会論文集, 138 号（昭和 50 年 12 月).

2) 高木 他 : 波浪による船内タンクの不規則応力推 定法, 関西造船協会誌, 156 号 (昭和 50 倬 3 月).

3) M.S. Longuet-Higgins et al : The statistical distribution of maxima of a random function, Proc. Roy. Soc. A, Vol. 237 (1956).

4）堀他：有限要素法プログラムに打けるData Generation, 日本造船学会誌, No. 554 (Aug. 1975).

5）日立造船 K. K. 編集 : 渡辺恵弘先生講義集（昭和 48 年 10 月).
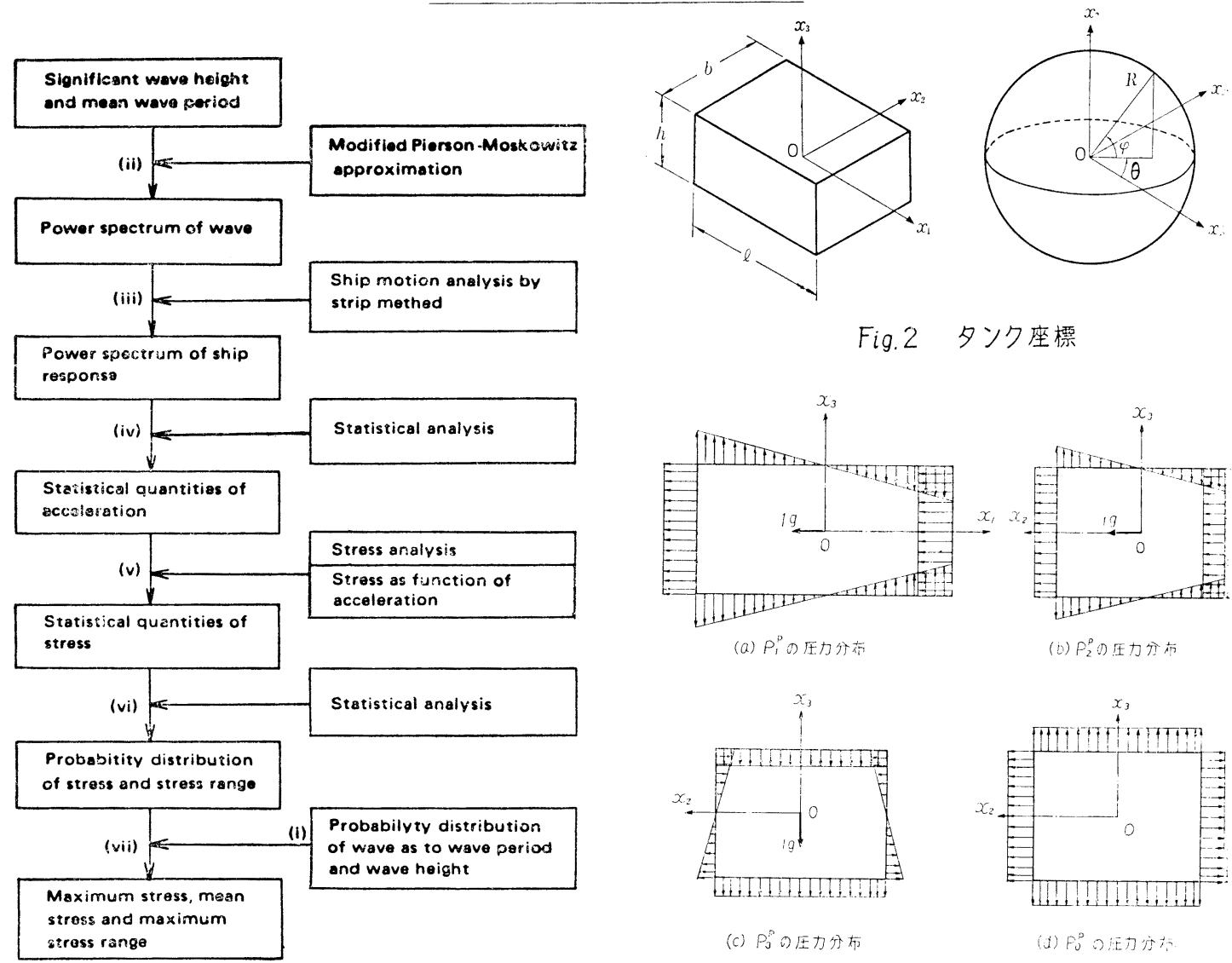

Fig.2 タンク座標

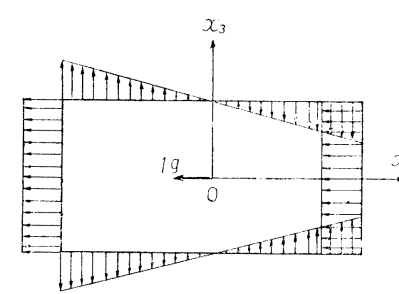

(a) P D D压力分萑

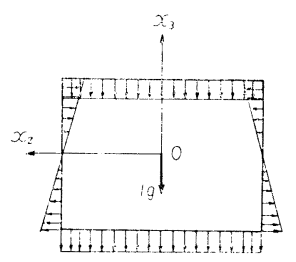

(c) P $P^{*} \oslash$ 压力分布

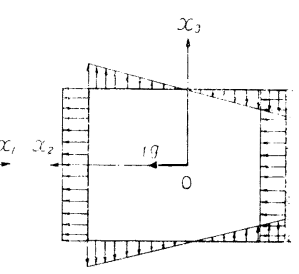

(b) $P_{2}^{0}$ 玨力学

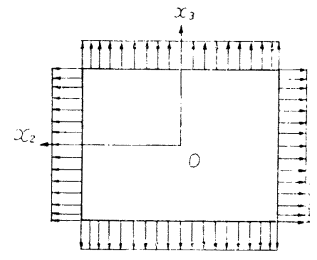

(d) Po ore住古

Fig. 1 态力掟フロー 


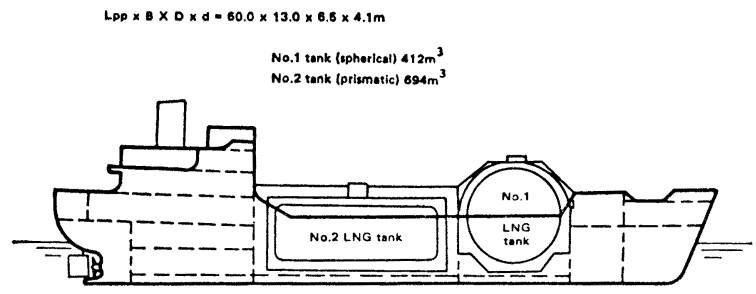

Fig.4 $1000 \mathrm{~m}^{3}$ 実轺船

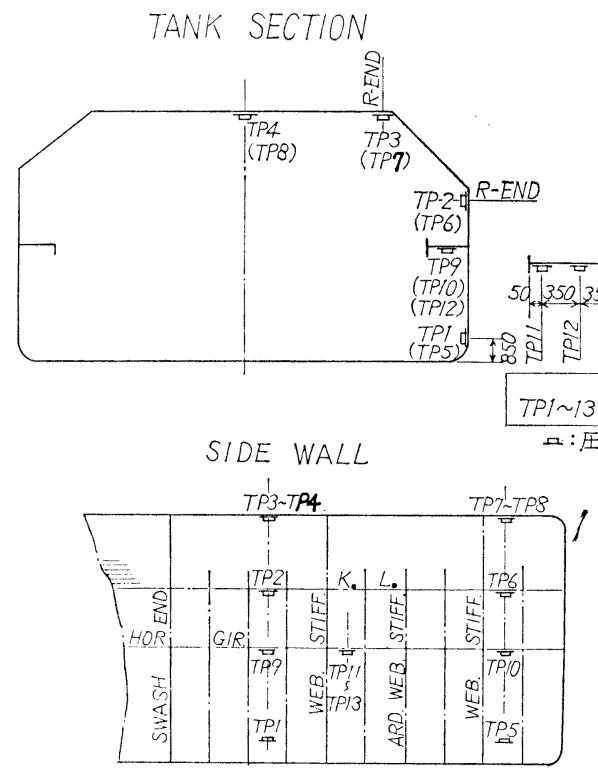

Fig.5 圧力計配置図(坊形勺ンク)

\section{Table 1 Test condition}

\begin{tabular}{|c|c|c|c|}
\hline condition & $\begin{array}{l}\text { Dato } \\
\text { (1974) }\end{array}$ & $\begin{array}{l}\text { Wevo } \\
\text { Heighto }\end{array}$ & $\begin{array}{l}\text { No.of } \\
\text { Trial }\end{array}$ \\
\hline $100 \%$ & $\begin{array}{r}6 / 12 \\
14 \\
15 \\
17 \\
18 \\
19 \\
7 / 7\end{array}$ & $\begin{array}{l}0.5 \mathrm{~m} \\
0.3 \\
0.2 \\
1.5 \\
2.0 \\
1.0 \\
3.0\end{array}$ & $\begin{array}{l}6 \\
8 \\
3 \\
6 \\
7 \\
6 \\
7\end{array}$ \\
\hline $76 \%$ & $6 / 21$ & 0.8 & 7 \\
\hline $60 x$ & $\begin{array}{r}6 / 24 \\
27 \\
28 \\
7 / 6 \\
\end{array}$ & $\begin{array}{l}0.5 \\
1.5 \\
0.8 \\
2.0 \\
\end{array}$ & $\begin{array}{l}7 \\
7 \\
7 \\
7 \\
\end{array}$ \\
\hline $100 \%$ & $\begin{array}{r}7 / 1 \\
2 \\
3 \\
4\end{array}$ & $\begin{array}{l}1.0 \\
1.5 \\
1.0 \\
2.0\end{array}$ & $\begin{array}{l}7 \\
7 \\
4 \\
2\end{array}$ \\
\hline $875 \%$ & 714 & 2.0 & 7 \\
\hline 200x & $7 / 6$ & 1.5 & 7 \\
\hline
\end{tabular}
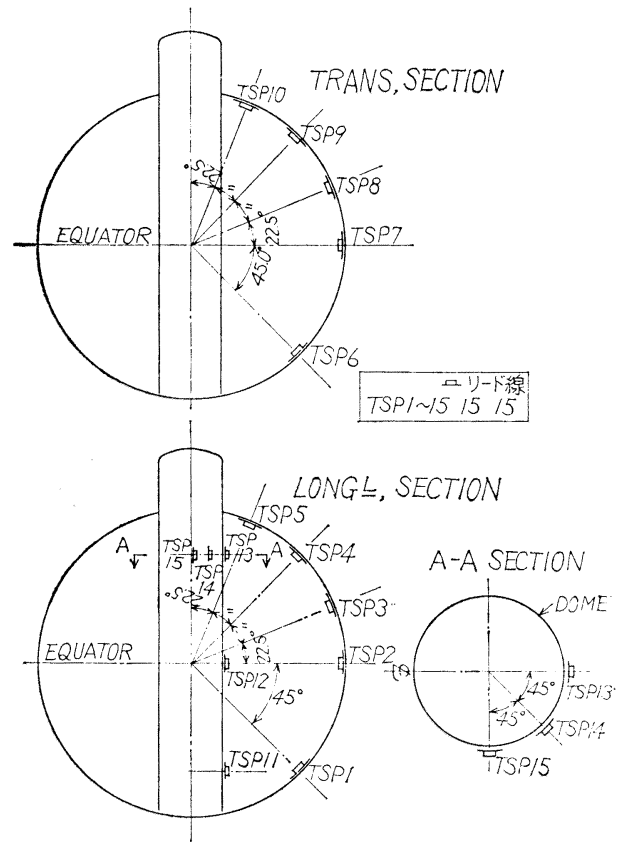

Fig.6 压力計配置図 (球形夕ンク)

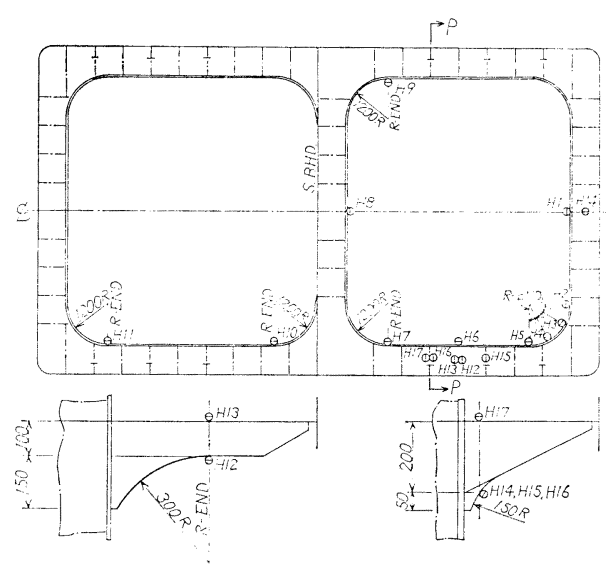

Fig.7 水平桁応力計測点

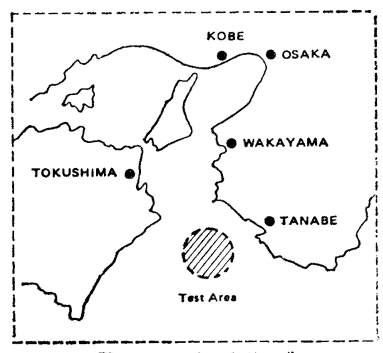

Fig.9 实呀海域 


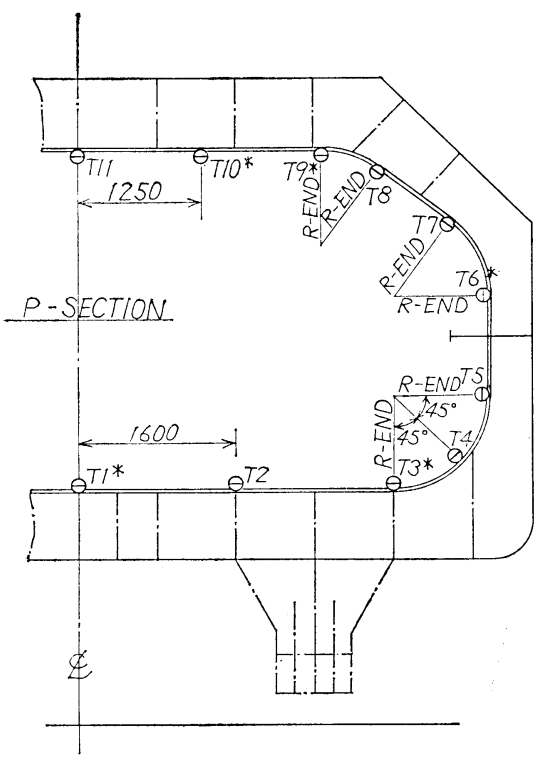

* 航走中実験計測点: TI,T3,T6,T9,T10

(係留中実験と供用)

他注係留中美験の外に使用

計測点数: 1方向ゲージ 5 点

$$
\text { リード線 } 5 \text { 本 }
$$

Fig.8トランスリング応力計測点

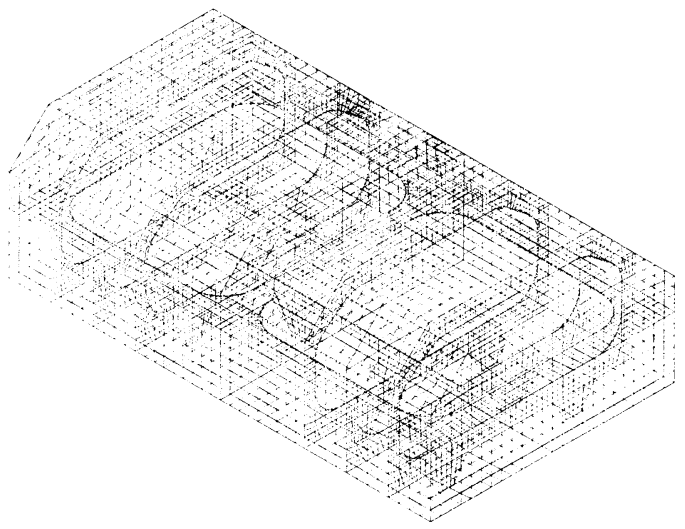

Fig.12 応力解析要素分割
IIMEHISTORY OF ACCELERAIIDN__ - IE1 -

$\left.0.200^{6}\right] \quad X-$ DIRECTION

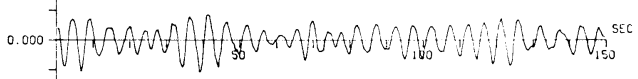

-

$\left.0.200^{G}\right] \quad Y$ - OIRECTION

-

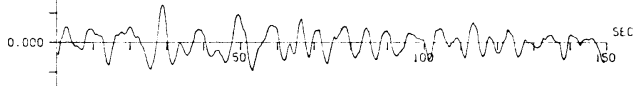

$-$

$-3,202]$

$0.200^{0} 7 \quad \underline{z}-$ DIRECTION

o.coothnfon

IJV V

$-0.2005$

Fig.10 加速度のTime History

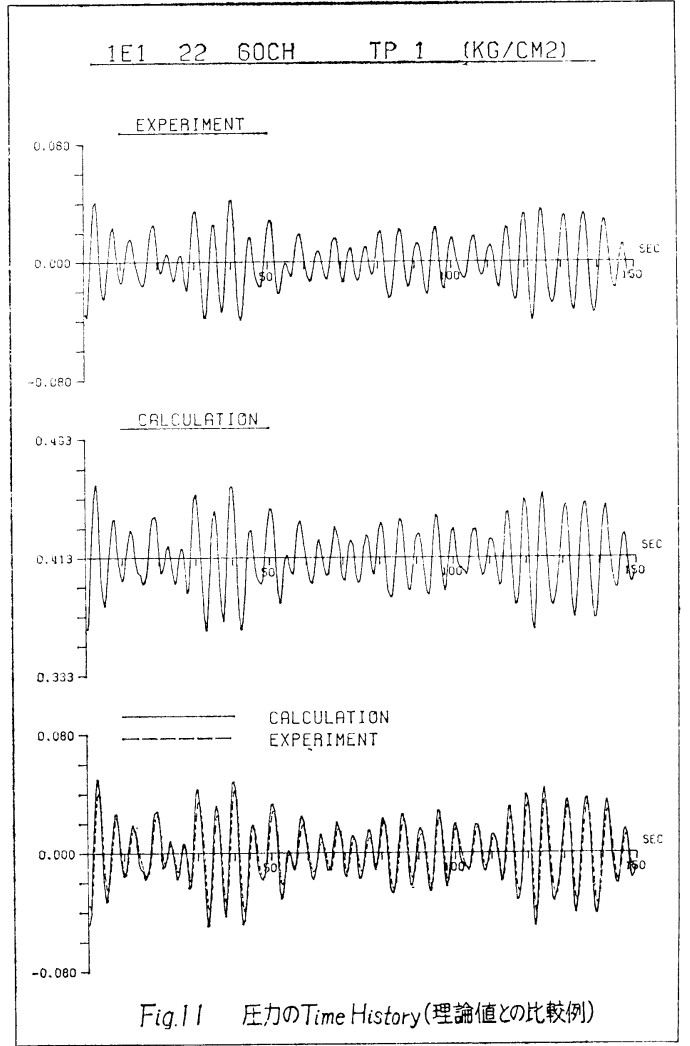




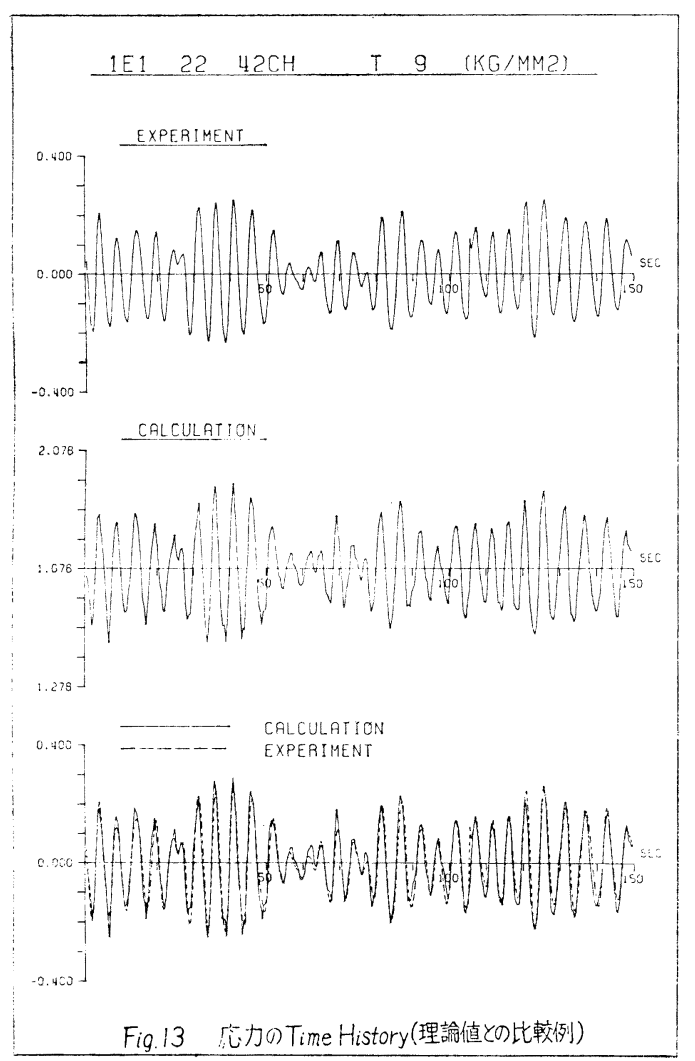

Table 2 応力係数

\begin{tabular}{|c|c|c|c|c|}
\hline 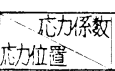 & $0.1 \sigma_{0}$ & $\sigma_{1}$ & $\sigma_{2}$ & $\sigma_{3}$ \\
\hline TI & -0.925 & 13.0 & -0.118 & -2.41 \\
\hline 13 & -0.715 & 2.20 & -1.06 & 7.93 \\
\hline To & $2.0 ?$ & -13.6 & 1.82 & -6.83 \\
\hline T9 & -0.510 & 5.20 & -0.627 & 2.95 \\
\hline$T 10$ & -0.886 & 5.35 & 2.50 & 3.53 \\
\hline $\mathrm{HI}$ & -2.59 & 20.0 & -0.041 & 4.81 \\
\hline H5 & 2.74 & -20.8 & 0.361 & -5.97 \\
\hline$H 7$ & -0.736 & -1.37 & -0.988 & 224 \\
\hline Hi & -0.227 & 4.09 & 0.012 & 2.45 \\
\hline $\mathrm{HO}$ & -0.736 & $-1.3 ?$ & 0986 & 2.23 \\
\hline
\end{tabular}

Table 3 相互作用の影響

\begin{tabular}{|c|c|c|c|c|c|c|c|}
\hline \multirow{2}{*}{\begin{tabular}{|l|} 
Ex. \\
No. \\
\end{tabular}} & \multirow{2}{*}{\begin{tabular}{|l|}
$\mathrm{H}$. \\
Angle \\
\end{tabular}} & \multicolumn{3}{|c|}{ T 9} & \multicolumn{3}{|c|}{ H 5} \\
\hline & & (1) & (2) & (1)/(2) & (1) & (2) & (i) $/$ (c) \\
\hline 1 & $\downarrow$ & 0.112 & 0.120 & 0.93 & 0.142 & 0.423 & 0.34 \\
\hline 2 & $\uparrow$ & 0.041 & 0.047 & 0.87 & 0.060 & 0.107 & 0.56 \\
\hline 3 & $\nearrow$ & 0 & 057 & 3 & 56 & 0.110 & 0.51 \\
\hline 4 & $\swarrow$ & $0 c$ & 0.120 & 0.85 & 4 & 394 & 0.34 \\
\hline 5 & $\leftarrow$ & 0.111 & 0.121 & 0.92 & 0.124 & 0.268 & 0.46 \\
\hline 6 & $\pi$ & 0.066 & 0.069 & 0.97 & 0.056 & 0.122 & 0.46 \\
\hline 7 & $\swarrow$ & 0.088 & 0.108 & 0.81 & 0.119 & 0.355 & 0.34 \\
\hline 累積 & & 0.086 & 0.096 & 0.90 & 0.105 & 0.285 & 0.37 \\
\hline
\end{tabular}

(1) タンク内圧力のみによる応力

(2) 船との相互作用を含んだ応力

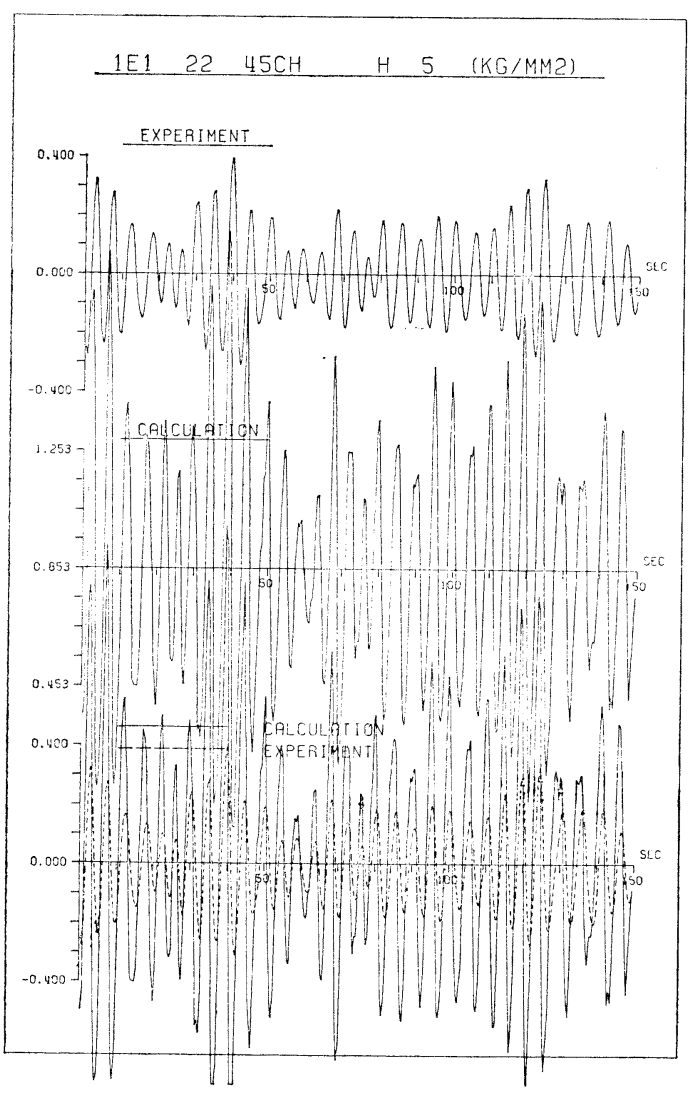

Fig.14 応办のTime History(理論值との比教例) 
Table 4 加速度成分間の相関の影響

\begin{tabular}{|c|c|c|c|c|c|c|c|}
\hline Ex. & H. & \multicolumn{2}{|c|}{$T 9$ (標䓥偏差) } & \multicolumn{3}{|c|}{ H5 (標準偏差) } \\
\cline { 3 - 9 } No. & Angle & $(1)$ & $(2)$ & $(1 / 2)$ & $(1)$ & $(2)$ & $(1) /(2)$ \\
\hline 1 & $\downarrow$ & 0.128 & 0.120 & 1.07 & 0.423 & 0.423 & 1.00 \\
\hline 2 & $\uparrow$ & 0.040 & 0.047 & 0.85 & 0.109 & 0.107 & 1.02 \\
\hline 3 & $\nearrow$ & 0.047 & 0.057 & 0.82 & 0.114 & 0.110 & 1.04 \\
\hline 4 & $\swarrow$ & 0.132 & 0.120 & 1.10 & 0.391 & 0.394 & 0.99 \\
\hline 5 & $\leftarrow$ & 0.120 & 0.121 & 0.99 & 0.278 & 0.268 & 1.04 \\
\hline 6 & $\nearrow$ & 0.055 & 0.069 & 0.80 & 0.125 & 0.122 & 1.02 \\
\hline 7 & $\swarrow$ & 0.119 & 0.108 & 1.10 & 0.358 & 0.355 & 1.01 \\
\hline 累積 & & 0.099 & 0.096 & 1.03 & 0.285 & 0.285 & 1.00 \\
\hline
\end{tabular}

(1) (7)式による計算値

(2)(10)式によって得た数值実験 TimeHistoryから得られた值

Table 5 バンド幅の比較(計測点H5)

\begin{tabular}{|l|c|c|c|c|c|c|c|}
\hline Ex. No. & 1 & 2 & 3 & 4 & 5 & 6 & 7 \\
\hline H.Angle & $\downarrow$ & $\uparrow$ & $\nearrow$ & $\swarrow$ & $\leftarrow$ & $\nearrow$ & $\swarrow$ \\
\hline 実験值 & 0.215 & 0.734 & 0.794 & 0.441 & 0.569 & 0.679 & 0.467 \\
\hline 計算值 & 0.281 & 0.555 & 0.546 & 0.329 & 0.362 & 0.536 & 0.321 \\
\hline
\end{tabular}

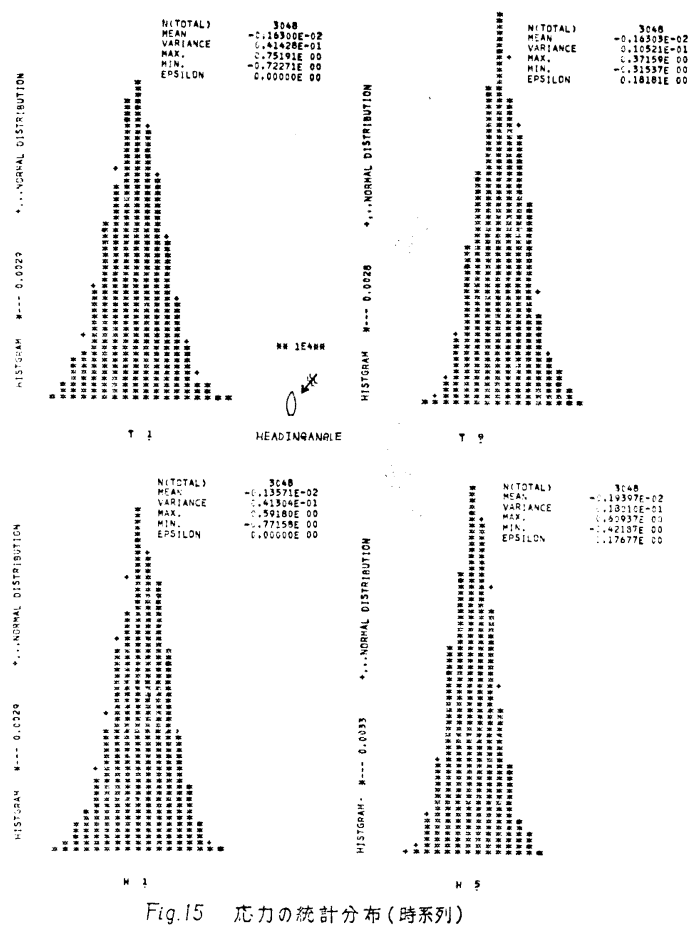

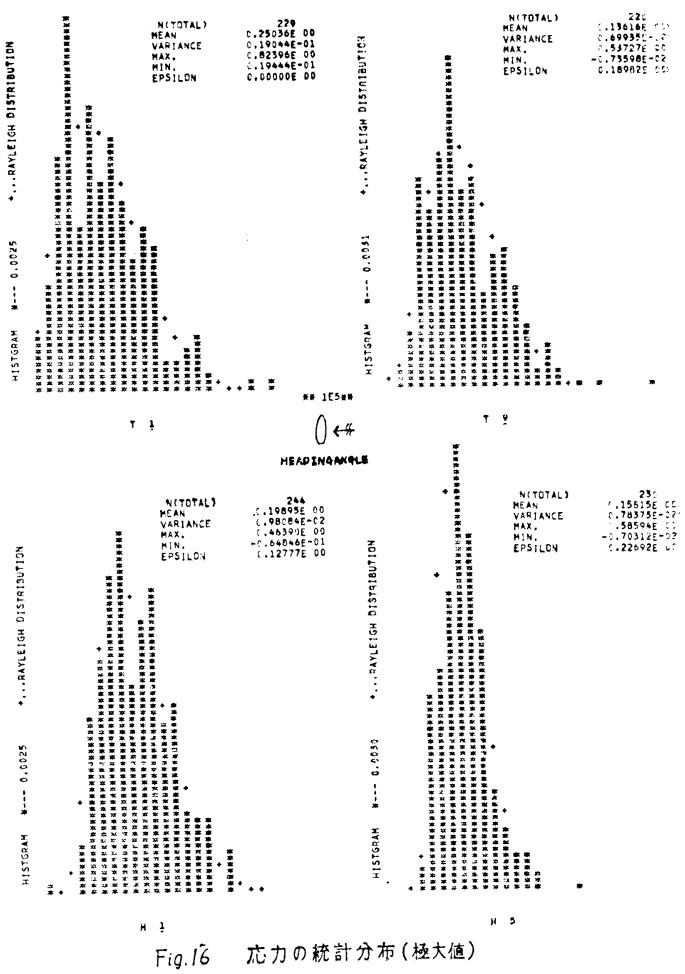

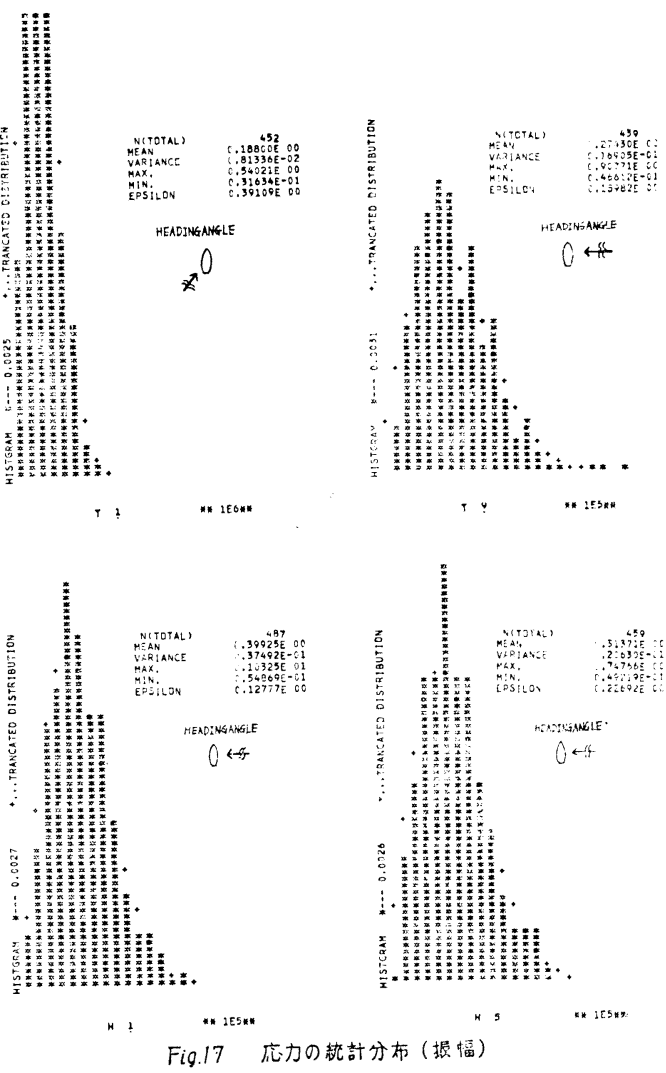

